\title{
Elbow Injuries and Treatment
}

Editor

JEFFREY R. DUGAS

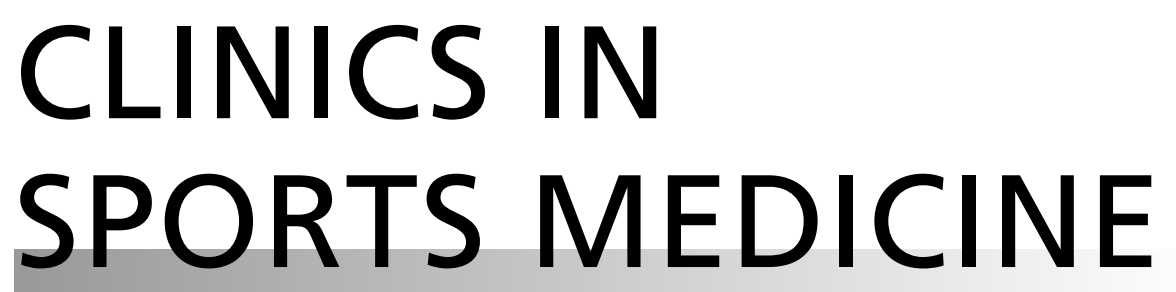

www.sportsmed.theclinics.com

Consulting Editor

MARK D. MILLER

July 2020 • Volume 39 • Number 3 